\title{
Genomic landscape of gastric cancer: molecular classification and potential targets
}

\author{
Jiawei Guo, Weiwei Yu, Hui Su \& Xiufeng Pang* \\ Shanghai Key Laboratory of Regulatory Biology, Institute of Biomedical Sciences and School of Life Sciences, East China Normal University, \\ Shanghai 200241, China
}

Received February 10, 2016; accepted April 6, 2016; published online July 25, 2016

\begin{abstract}
Gastric cancer imposes a considerable health burden worldwide, and its mortality ranks as the second highest for all types of cancers. The limited knowledge of the molecular mechanisms underlying gastric cancer tumorigenesis hinders the development of therapeutic strategies. However, ongoing collaborative sequencing efforts facilitate molecular classification and unveil the genomic landscape of gastric cancer. Several new drivers and tumorigenic pathways in gastric cancer, including chromatin remodeling genes, RhoA-related pathways, TP53 dysregulation, activation of receptor tyrosine kinases, stem cell pathways and abnormal DNA methylation, have been revealed. These newly identified genomic alterations await translation into clinical diagnosis and targeted therapies. Considering that loss-of-function mutations are intractable, synthetic lethality could be employed when discussing feasible therapeutic strategies. Although many challenges remain to be tackled, we are optimistic regarding improvements in the prognosis and treatment of gastric cancer in the near future.
\end{abstract}

gastric cancer, chromatin remodeling, RhoA, p53, receptor tyrosine kinase, DNA methylation

Citation: Guo, J., Yu, W., Su, H., and Pang, X. (2017). Genomic landscape of gastric cancer: molecular classification and potential targets. Sci China Life Sci 60, 126-137. doi: 10.1007/s11427-016-0034-1

\section{INTRODUCTION}

With more than 900,000 new cases being reported every year, gastric cancer has become the fourth most commonly diagnosed cancer in the world (Jemal et al., 2011), and its death rate ranks as the second highest worldwide (Siegel et al., 2013). People in Asia, Eastern Europe and South America present the highest mortality of gastric cancer due to its high incidence (Siegel et al., 2013). In recent years, despite improvements in prognosis after the application of cisplatin and fluoropyrimidine-based chemotherapies, surgery remains the only curative therapy (Ryu et al., 2014). Unfortunately, highly frequent relapse, as well as distant metastases, ensure that the five-year survival of gastric cancer rarely exceeds 10\% (Group et al., 2010; Siegel et al., 2013). Therefore,

*Corresponding author (email: xfpang@bio.ecnu.edu.cn) more effective therapeutic approaches are urgently needed.

A better understanding of the mechanisms underlying gastric cancer tumorigenesis is of crucial significance for conquering the disease. Major molecular biological advances have resulted in the better survival of gastric cancer patients (Yang et al., 2014). Small subsets of gastric cancers are defined by biomarkers, including the overexpression of HER2 (epidermal growth factor receptor kinase 2) protein and amplification of its gene ERBB2. These biomarkers have led to the first targeted treatment approach for gastric cancer. The clinical trial of trastuzumab, an antiHER2 antibody, showed that the use of trastuzumab for the treatment of HER2-overexpressing gastric cancer patients improved their overall survival compared with standard platinum- and fluoropyrimidine-based chemotherapy (Gravalos et al., 2011). Moreover, functional genomic alterations, e.g., c-MET activation, have been identified as addi- 
tional biomarkers that would benefit these personalized treatments. However, the increasing knowledge of gastric cancer etiology has given rise to the realization that gastric cancer is characterized by molecular complexity. Recently published comprehensive genomic analyses of gastric cancer not only challenge the traditional clinical classification of gastric cancer but lead to much-needed new targets for drug development and therapeutic strategies (Kakiuchi et al., 2014; Liang et al., 2012; Wang et al., 2011, 2014; Zang et al., 2012).

Because advancing genomic technologies continue to refine the molecular biology of gastric cancer, this review focuses on new insights into the genetics of gastric cancer revealed by recent next-generation sequencing studies. We describe functional genetic alterations in gastric cancer and provide several rational strategies that may broaden the range of clinical therapeutic approaches for gastric cancer.

\section{GENOMIC LANDSCAPE AND MOLECULAR CLASSIFICATION}

In 2014, The Cancer Genome Atlas (TCGA) project analyzed the genomic landscape of 295 primary gastric adenocarcinoma tumor tissues (Cancer Genome Atlas Research, 2014) through genome sequencing and comprehensive molecular evaluations. These analyses led to the proposal of a new molecular classification for gastric cancer. Gastric adenocarcinomas traditionally varied from intestinal-type gastric carcinomas (IGCs) to diffuse-type gastric carcinomas (DGCs) in terms of their histological heterogeneity according to the Lauren classification system (Lauren, 1965). In 2010, the World Health Organization proposed a division of gastric cancer into papillary, tubular, mucinous (colloid) and poorly cohesive carcinomas. However, these classification systems show little clinical therapeutic utility. Fortunately, new molecular classifications that were recently confirmed by genome sequencing analysis provide a guide to targeted agents that should be evaluated through clinical trials for distinct gastric cancer patients.

Gastric cancer is divided into four subtypes according to the new molecular classification (Figure 1): tumors positive for Epstein-Barr virus (EBV), tumors with microsatellite instability (MSI), genomically stable tumors (GS), and tumors with chromosomal instability (CIN) (Cancer Genome Atlas Research, 2014). These molecular subtypes show distinct genomic features. EBV-infected tumors are chromosomally stable but present a significantly enriched EBV burden, showing extensive genome-wide hypermethylation and minimal demethylation (Cheng et al., 2015; Strong et al., 2013). In addition, EBV-infected tumors display frequent ARIDIA, BCOR and PIK3CA mutations, 9p chromosome amplification, and lack of TP53 mutations, which contrasts with the high TP53 mutation frequency observed in CIN and MSI tumors (Cancer Genome Atlas Research, 2014; Wang et al., 2014). MSI tumors additionally exhibit a high prevalence of DNA promoter hypermethylation, such as at the $M L H 1$ promoter, which is different from EBV-associated DNA hypermethylation (Leite et al., 2011; Park et al., 2013). MSI tumors exhibit elevated mutation frequencies of genes encoding targetable oncogenic proteins (TP53, KRAS, ARIDIA, PIK3CA, ERBB3, $P T E N$ and $H L A-B$ ) (Cancer Genome Atlas Research, 2014; Wang et al., 2014). Although few clear targets are observed, GS tumors are enriched in both the diffuse histological variant and mutations of $C D H 1, R H O A$ or fusions of RHO-family GTPase-activating proteins. CIN tumors are characterized by extensive frequencies of TP53 mutation (71\%), CDH1 mutation (37\%), marked aneuploidy and focal amplification of receptor tyrosine kinases that are clinically therapeutic targets (Cancer Genome Atlas Research, 2014). The use of genomic landscaping and molecular classification may provide a valuable adjunct to histopathology and a roadmap for gastric cancer patient stratification and trials of targeted therapies.

\section{POTENTIAL TARGETS}

\section{Chromatin remodeling genes}

Nearly half of gastric cancers harbor mutations in chromatin remodeling genes (Zang et al., 2012). ARIDIA, the AT-rich interacting domain containing protein $1 \mathrm{~A}$, is one of the most commonly mutated chromatin remodeling genes and has
EBV

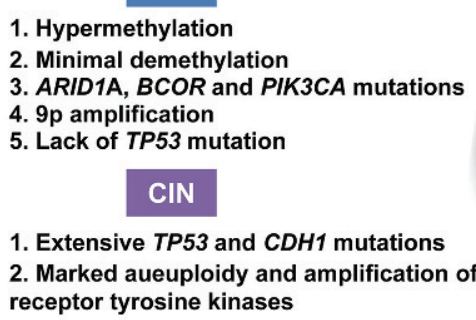

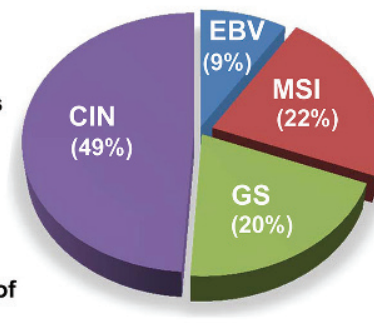

MSI

1. DNA promoter hypermethylation

2. Elevated mutations of oncogenic proteins

\section{CS}

1. Diffuse histological variant 2. CDH1 and RHOA mutations

3. Fusion of RHO-family GTPase-activating proteins

Figure 1 Key features of gastric cancer subtypes. The schematic shows several salient characteristics of four molecular subtypes of gastric cancer. The frequency of each tumor subtype is also listed. EBV, tumors with Epstein-Barr virus; MSI, microsatellite unstable tumors; CIN, tumors with chromosomal instability; GS, genomically stable tumors. 
been reported to exhibit a mutation frequency ranging from $8 \%$ to $27 \%$ in gastric cancer samples (Abe et al., 2012; Inada et al., 2015; Wang et al., 2012). The majority of ARIDIA mutations are frameshift or nonsense mutations that ultimately cause reduced expression of ARID1A protein in the cells (Wang et al., 2011; Zang et al., 2012). The function of ARID1A is mainly involved in DNA mismatch repair (Inada et al., 2015). Therefore, the loss of ARID1A may lead to genomic instability.

Although the tumor suppressor role of ARID1A has been confirmed (Guan et al., 2011; Zang et al., 2012), it remains difficult to restore the weakened expression of ARID1A in patients. In addition, effective therapeutic approaches to target cancer with ARIDIA mutations have yet to be elucidated (Kim et al., 2012). Fortunately, synthetic lethality provides new insights regarding approaches to target cancer cells with ARIDIA aberrations. Synthetic lethality exploits the fact that many cancer cells acquire defects in DNA repair pathways and become dependent on a compensatory mechanism to survive (Farmer et al., 2005; Jekimovs et al., 2014). Inhibition of the compensatory DNA repair pathway selectively kills cancer cells with a defect in a particular DNA repair pathway. Because ARID1A plays a key role in chromatin remodeling (Inada et al., 2015), the loss of its function makes cells rely on other compensatory pathways for maintenance of genomic stability and promotion of survival. Therefore, it may be feasible to identify pathways that compensate for the reduced expression of ARID1A. EZH2 methyltransferase, the catalytic subunit of polycomb repressive complex 2, was recently identified as one such factor (Bitler et al., 2015) that shares a synthetic lethal relationship with ARID1A aberrations. EZH2 helps maintain genomic stability via generation of the lysine 27 trimethylation mark on histone H3 (H3K27 Me3) by its catalytic SET domain (Cao and Zhang, 2004). EZH2 inhibition causes regression of ARIDIA-mutated ovarian tumors in vivo, but this effect has not been confirmed in ARIDIA-mutated gastric cancer. Nevertheless, EZH2 inhibition may be a rational and promising therapeutic approach for gastric cancer treatment.

In addition to EZH2 methyltransferase, the PI3K/Akt pathway is another key pathway that acts in a synthetically lethal manner in tumors with defective ARID1A (Zang et al., 2012). ARIDIA mutations were found to be significantly associated with tumors harboring PIK3CA-activating mutations (Yamamoto et al., 2012) or loss of PTEN expression (Bosse et al., 2013). ARID1A-deficient cells demonstrate an increased phosphorylation of Akt at the Ser473 site (Liang et al., 2012). These data suggest that loss of ARID1A expression sensitizes cancer cells to PI3K or Akt inhibitors (Samartzis et al., 2014). Because PI3K inhibitors are currently under clinical evaluation in gastric cancer (Fuereder et al., 2011), it will be necessary to perform a pre-selection of patients with respect to their ARID1A status prior to treatment with PI3K or Akt inhibitors.

Apart from ARID1A, other members of the SWI-SNF complex (ARIDIB, PBRMI and SMARCC1), ISWI complex (SMARCA1) and NuRD complex (CHD3, CHD4 and $M B D 2)$ as well as other genes encoding histone-modifying proteins (SIRT1 and SETD2), are also mutated in 59\% of gastric cancers (Zang et al., 2012). Moreover, histone methyltransferase genes and epigenetic modifier genes also mutate at a relatively high frequency in gastric cancer. Other genes involved in the maintenance of genomic stability may also be inactivated in gastric cancer. $B R C A 1$ or $B R C A 2$ inactivation, which occurs in approximately $10 \%$ of gastric cancer patients, is closely correlated to PARP1 function (Farmer et al., 2005). This synthetic lethal relationship has led to the exploitation of PARP1 inhibitors in the treatment of BRCAl-inactivated breast cancer (Bryant et al., 2005). Further investigation in synthetic lethality may provide additional avenues that will broaden the horizon of targeted therapeutic strategies for gastric cancer.

\section{RhoA-related pathways}

Rho GTPases are subsets of the Ras superfamily that regulate and coordinate cell motility, the cell cycle, cell cytoskeleton remodeling and other cellular processes (Iden and Collard, 2008; Lu et al., 2009b; Narumiya et al., 2009; Sahai and Marshall, 2002). RhoA, an important member of the Rho GTPase subsets, plays a critical role in stress fiber formation, which is involved in cell invasion, metastasis and tumorigenesis through its downstream effectors, including ROCK1, protein kinase $\mathrm{N}, \mathrm{mDia}$ and citron ( $\mathrm{Lu}$ et al., 2009b; Narumiya et al., 2009). In breast cancer, esophageal squamous cell carcinoma, colon cancer and other solid tumors, RhoA protein is overexpressed and serves as a quantitative marker for prediction of the progression stage and prognosis in a molecular detection strategy (Bellizzi et al., 2008; Fritz et al., 1999; Fukui et al., 2006; Malissein et al., 2013; Zhang et al., 2013). Ras ${ }^{\mathrm{V} 12}$ and loss of p53 synergistically induce RhoA activity (Xia and Land, 2007). More recently, several studies have discovered novel mutations of RHOA ( $14.3 \%$ to $25.3 \%)$ and somatic genomic alterations of RhoA-related Rho-GAPs in GS tumors with diffuse-type histological characteristics; however, these have rarely been observed in other gastric cancer subtypes (Cancer Genome Atlas Research, 2014; Kakiuchi et al., 2014; Wang et al., 2014; Zhou et al., 2014), suggesting that the RhoA-related pathway might be a novel signaling driver in GS tumors.

Recurrent inactivating mutations in RhoA GTPase have been reported in T cell lymphoma (Cools, 2014; Palomero et al., 2014; Sakata-Yanagimoto et al., 2014; Yoo et al., 2014). In GS tumors, mutant RhoA encodes known functional domains related to effector interaction or GTP binding, working in a gain-of-function manner (Kakiuchi et al., 2014). The Tyr42, Arg5 and Gly17 residues in RhoA pro- 
tein have been identified as key mutation hotspots (Cancer Genome Atlas Research, 2014; Kakiuchi et al., 2014). The Tyr42 mutation attenuates the activation of protein kinase $\mathrm{N}$ but does not affect mDia activation (Cancer Genome Atlas Research, 2014). The TCGA project detected missense mutations at Tyr42 and Asp59 of GTPase-RhoA and mapped them onto the structures of RHOA and ROCK1 (Cancer Genome Atlas Research, 2014). Four alterations in the effector domain (Tyr34, Phe39, Glu40 and Try42 sites) have been shown to impair the binding of RhoA to its effector proteins (Wang et al., 2014). In addition to RhoA mutations that drive GS tumors by disrupting Rho signaling, the TCGA project further found RHOA-COL7A1 and COL27A1-ZNF618 fusions in GS tumors (Cancer Genome Atlas Research, 2014; Ushiku et al., 2015; Wang et al., 2014).

Gain-of-function and structural variants of RhoA dysregulate Rho signaling and triggers an invasive phenotype in diffuse GC. Agents targeting RhoA itself, e.g., ROCK I, ROCK II and other effectors in the RhoA oncogenic pathways, have shown therapeutic benefits in cardiovascular disease, urogenital disorders and in other types of cancer (Gur et al., 2011; Nunes et al., 2010), suggesting a therapeutic potential for GS tumors (Sadok et al., 2015; Shang et al., 2012). The selective Rho-kinase inhibitors Y-27632 and Fasudil have been tested in pre-clinical and clinical studies (Molli et al., 2012; Olson, 2008). Y-27632 exhibits an anti-tumor effect against Ehrlich's ascites carcinoma in mice through binding to the Rho-kinase ATP binding pocket in an ATP-competitive manner (Olson, 2008). In different cell lines, including cells isolated from a chronic myeloid leukemia patient (Molli et al., 2012), myeloid cells bearing oncogenic forms of KIT, FLT3 and BCR-ABL (Mali et al., 2011) and human colon cancer cells (Attoub et al., 2002), the Clostridium botulinum C3 exoenzyme could inhibit Rho ADP-ribosylation to trigger cell apoptosis and decrease cell proliferation. A small molecular compound, Rhosin, a RhoA inhibitor, was discovered through virtual screening (Shang et al., 2012). Rhosin exhibits dose-ependently inhibitory activity toward RhoA by targeting the GEF-interactive site of RhoA. Moreover, Rhosin also suppresses the invasion of mammary epithelial cells and mammary sphere formation (Shang et al., 2012). Compound Y16 works synergistically with Rhosin in the inhibition of LARG-RhoA interaction, RhoA activation and RhoA-diated signaling by targeting G-protein-coupled Rho guanine nucleotide exchange factors. The combination of Y16 and Rhosin effectively inhibits the growth, migration and invasion of breast cancer cells (Shang et al., 2013). To date, no inhibitors of RhoA signaling pathways have progressed into standard clinical therapy. However, the optimization of such inhibitors could be useful for future gastric cancer treatments.

\section{TP53 dysregulation}

TP53 mutations have been observed in approximately $40 \%$ of gastric cancers (Iwamatsu et al., 2001; Oki et al., 2009), making it one of the most prevalent genetic alterations in gastric cancer. In addition to mutations at six discrete hotspot codons within the DNA-binding domain of TP53, loss of heterozygosity (LOH) of the TP53 gene is a main reason for the loss-of-function of p53 (Kobayashi et al., 1996; Smith et al., 2006; Tahara, 2004). Although the prognostic impact of TP53 abnormalities in gastric cancer remains controversial (Gamboa-Dominguez et al., 2007; Lee et al., 2014; Liu et al., 2012; Sumiyoshi et al., 2006; Wei et al., 2015), the correlation between TP53 abnormalities and the occurrence of aneuploidy is becoming increasingly clear (Cesar et al., 2004; Gobbo Cesar et al., 2006; Lu et al., 2009a). This finding is reasonable because the maintenance of genome stability is one of the key roles of p53 (Belyi et al., 2010), often called "the guardian of the genome" (Suzuki and Matsubara, 2011). Data from recently published second-generation sequencing studies (Cancer Genome Atlas Research, 2014; Wang et al., 2014) also support this notion that a cluster of TP53 mutations is observed in one of the specific subtypes of gastric cancer, specifically gastric tumors with CIN. Because TP53 alterations are closely associated with gastric cancer tumorigenesis, it is better to discuss gastric cancer treatments with respect to the p53 status.

One feasible therapeutic approach to target p53-deficient tumors is to restore the function of p53. To achieve this goal, a recombinant adenovirus encoding p53 has been developed (Jekimovs et al., 2014). The results from clinical trials with two of the adenovirus-mediated p53 (Ad-p53) cancer gene therapies, advexin (Senzer and Nemunaitis, 2009; Wolf et al., 2004) and SCH-58500 (Atencio et al., 2006; Buller et al., 2002), demonstrated the safety and feasibility of their administration. However, the anti-tumor efficacy of these therapies has been limited in some cancer patients. This insufficiency may be attributed to the low transduction of p53 into cancer cells via these Ad-p53 vectors. To overcome these transduction defects, competent oncolytic adenoviruses (CRAd-p53) vectors have been developed. The CRAd-p53 vectors exploit the promoters of cancer-related genes to maintain a stable and high virus expression. Initial in vitro and in vivo studies focused on AdDelta24-p53 (van Beusechem et al., 2002), SG600-p53 (Wang et al., 2008) and OBP-700 (Yamasaki et al., 2012) demonstrated their equivalent safety and improved antitumor effects compared with those of their Ad-53 counterparts. The efficacy of recombinant Ad-p53 in gastric cancer cell lines was recently proven either as a monotherapy or in combination with oxaliplatin (Chen et al., 2011). However, its in vivo anti-tumor activity in the treatment of gastric cancer awaits further investigation. 
Although tumor suppressor genes such as TP53 are rarely tractable, low-molecular-weight compounds capable of selectively targeting p53-deficient tumors were recently identified. One of the most effective p53 reactivators, PRIMA-1 (Bykov et al., 2002), is able to restore the specific DNA binding and transcriptional transactivation function to mutant p53 by stabilizing the p53 core domain and promoting wild-type folding. The administration of PRIMA-1 leads to p53-dependent apoptosis in a range of tumors with p53 deficiency. APR-246 (PRIMA-1 MET), similarly to its analog, was tested in a Phase I/II clinical trial with promising results (Lehmann et al., 2012). Another recently reported promising compound that targets p53-deficient cancers is an FDA-approved drug for the treatment of type 1 and type 2 diabetes (Venkatanarayan et al., 2015). Pramlintide, a synthetic analogue of amylin, has been demonstrated to trigger rapid tumor regression in p53-deficient thymic lymphomas. This anti-tumor effect has been attributed to the ability of pramlintide and amylin to inhibit glycolysis and induce reactive oxygen species and apoptosis. These aforementioned sophisticated strategies to target p53-mutant cancers will provide novel insights into the treatment of gastric cancer.

\section{Receptor tyrosine kinases}

As one of the most frequently dysregulated pathways, receptor tyrosine kinases (RTKs) are activated by either copy number gains or hotspot mutations that maintain an active conformation of the protein kinase domain (Carrera et al., 2014). In gastric cancer, the majority of RTKs that show dysregulation is the epidermal growth factor receptor family (ERBB). Activation of ERBB2 (HER2) is found in approximately $17 \%$ of gastric cancer samples, and gene amplification is the main cause of this effect (Gravalos and Jimeno, 2008; Yano et al., 2006). This finding prompted the initiation of clinical trials of gastric cancer, which were designed to explore the efficacy of trastuzumab, a mAb against the extracellular domain of HER2 protein (Gravalos et al., 2011). The median overall survival rate was favorable for a trastuzumab-plus-chemotherapy arm with a $26 \%$ reduction in the death rate. These promising results prompted the approval of trastuzumab in 2013 for the treatment of gastric cancer. Apart from trastuzumab, ramucirumab, a fully human IgG1 anti-VEGFR-2 mAb, was approved in 2015 for patients with gastric cancer or GEJ (gastro-esophageal junction) adenocarcinoma who show progression following fluoropyrimidine or platinumcontaining chemotherapy.

Although the clinical application of trastuzumab and ramucirumab improves the overall survival rate of gastric cancer patients, treatment resistance is inevitable. Primary resistances as well as required resistances, are the major reasons for the treatment failure observed in patients.
Because PIK3CA is one of the main downstream effectors of RTK signaling, its hotspot mutations that lead to constitutive PI3K pathway signaling even in the absence of growth factors usually induce primary resistance to RTK inhibition (Velho et al., 2005). Because nearly $80 \%$ of EBV-positive gastric cancer tumors harbor altered PIK3CA (Cancer Genome Atlas Research, 2014), it is necessary to conduct a pre-selection of patients with respect to the status of PIK3CA and its suppressor gene, PTEN, prior to onset of trastuzumab treatment. In HER2-overexpressing tumors, the predominant mechanism of resistance is compensatory signaling by other cell-surface receptors, including the reprogramming of IGF1R, MET, GDF15 and other members of the ERBB family (Nahta, 2012). Because the PI3K pathway is commonly shared by different RTKs, its inhibitors may be a useful option for overcoming trastuzumab resistance in the future. Other mechanisms underlying treatment resistance include the expression of a selectively truncated version of HER2 (Molina et al., 2001; Nagy et al., 2005), alterations of focal adhesion kinases FAK and Src (Gong et al., 2004) and STAT3 activation (Korkaya et al., 2012). It has now become increasingly clear that cancer cells have many redundant mechanisms that confer resistance to targeted therapies and that rational drug combinations are needed to achieve enhanced efficacy.

\section{Stem cell pathways}

Aberrations in stem cell pathways result in fibrosis, degenerative diseases and cancer. Transforming growth factor $\beta$ (TGF- $\beta$ ), Wnt and hedgehog signaling are pivotal pathways that influence the cell division, invasion, migration and ulcer repair processes (An et al., 2013; Lagasse, 2008; Zhao, 2014). Disorders in these processes usually lead to gastric adenocarcinoma and other tissue-specific gastrointestinal cancers (Stojnev et al., 2014). Genome sequencing and comprehensive molecular profiling have identified novel driver mutations involved in stem cell pathways in gastric cancer.

Genes in the TGF- $\beta$ pathway have been predicted to be key drivers in both MSI and other types of gastric cancers (Mishra et al., 2005; Wang et al., 2014). TGFBR2, $A C V R 2 A$, SMAD4, SMAD2 and ELF3 mutations have been observed in MSI tumors and microsatellite-stable (MSS) tumors (Cancer Genome Atlas Research, 2014; Wang et al., 2014). ELF, the TGF- $\beta$ adaptor protein, and the common mediator Smad4 are important for the maintenance of cell structure and the conferment of cell polarity (Katuri et al., 2006; Levy and Hill, 2005). Inactivating mutations in ELF3 in gastric cancer may particularly lead to the silencing of TGF- $\beta$ signaling through reduced TGFBR2 expression (Park et al., 2001). Additionally, inactivating mutations in $T G F-\beta$ also occur in pancreatic carcinomas and colon cancers (Katuri et al., 2006). Loss of expression of Smad4 and 
ELF in advanced colorectal cancer is indicative of poor prognosis (Tang et al., 2005). In such cases, tumor cells may enhance their own proliferative, invasive and metastatic behavior through other aspects of TGF- $\beta$ signaling (Ikushima and Miyazono, 2010). Thus, TGF- $\beta$ signaling can switch from a tumor-suppressing to a tumor-activating function. TMEM16A, a membrane protein associated with calcium-dependent chloride channel activity (Caputo et al., 2008), has been reported to be significantly upregulated and amplified in gastric cancer tissues and contributes to tumor invasion and poor prognosis of gastric cancer through the TGF- $\beta$ pathway (Liu et al., 2015).

Recurrent mutations in genes encoding Wnt pathway molecules, such as $A P C, M A C F 1$ and $C T N N B 1$, have frequently been found in both DGCs and IGCs (Anastas and Moon, 2013; Kakiuchi et al., 2014). CTNNA2, which encodes one component of cell-adhesion complexes, is mutated in $6.4 \%$ of MSS tumors, and this mutation has been identified as a novel driver mutation in gastric cancer (Wang et al., 2014). RNF43, which encodes an E3 ubiquitin ligase involved in the deregulation of the Wnt pathway, is also inactivated by mutation in MSS tumors (Koo et al., 2012). Several targeted agents of Wnt signaling are being developed (An et al., 2014), including $\beta$-catenin-TCF antagonists and other mechanism-based inhibitors that principally target enzymes (Kahn, 2014). All of these agents are still in their infancy and need to be evaluated for their clinical efficacy and safety in gastric cancer patients. Nevertheless, some nonspecific modulators affect the Wnt pathway, such as non-steroidal anti-inflammatory drugs (NSAIDs) (Baron et al., 2003; Sandler et al., 2003), COX2 inhibitor (Grosch et al., 2001; Xie et al., 2012), vitamins (Klampfer, 2014; Larriba et al., 2011; So and Suh, 2015), polyphenols (Liu et al., 2008; Oh et al., 2014) and other FDA-approved drugs. In addition, the combination treatment of the ERK1/2 inhibitor PD98058 and DAPT, a potent secretase inhibitor, has been shown to markedly sensitize gastric cancer cells to apoptosis by suppressing $\beta$-catenin signaling (Yao et al., 2013).

Furthermore, GLI3 and ZIC4, which are involved in hedgehog signaling, are also important driver genes affecting a portion of MSS tumors (Wang et al., 2014). The hedgehog pathway inhibitors, vismodegib, which was approved in 2012 by the FDA for the treatment of locally advanced and metastatic basal cell carcinoma (BCC) (Chang et al., 2014; Sandhiya et al., 2013; Wilkes, 2012), has also been employed in the treatment of advanced gastric and gastroesophageal junction cancer. Patients administered FOLFOX and vismodegib simultaneously, achieved better median overall survival (vismodegib+FOLFOX, 14.9 months compared to FOLFOX, 11.5 months) (NCT00982592) (Cohen et al., 2013). BMS-833923, another SMO inhibitor, has also been combined with cisplatin and capecitabine for the treatment of inoperable metastatic gastric or gastroesophageal cancer patients (NCT00909402). Further clinical studies on hedgehog pathway inhibitors, such as vismodegib, BMS-833923, SARIDEGIB and LY2940680, are needed for gastric cancer (Justilien and Fields, 2015; Sandhiya et al., 2013).

Amplifications of the genes that encode the stem cell markers CD44 and CD24 and other stem cell signaling biomarkers constitute additional aberrations that have been reported in gastric cancer (Chen et al., 2012, 2013; Zhang et al., 2011b). These novel driver gene mutations of stem cell pathways may be exploited as biomarkers for the unveiling of potential therapeutic targets.

\section{Aberrant DNA methylation}

Cancer cells typically present aberrant DNA methylation, including peculiar gene promoter $\mathrm{CpG}$ island hypermethylation and global genomic DNA hypomethylation (He et al., 2015 ). These usually occur at the $5^{\prime}$ position of the cytosine ring within $\mathrm{CpG}$ dinucleotides, resulting in the silencing of genes and non-coding genomic regions (Cheng et al., 2013). Tumor-suppressor gene methylation is one of the most well-defined epigenetic alterations involved in gastric carcinogenesis (Qu et al., 2013). Approximately 400 genes are actively expressed in normal gastric epithelial cells, but these genes can be inactivated in gastric cancers through hypermethylation of their gene promoter $\mathrm{CpG}$ islands (Kang, 2012). Aberrant gene promoter $\mathrm{CpG}$ island hypermethylation occurs early in multi-stage gastric carcinogenesis and tends to increase in a step-wise manner in the progression toward malignancy (Cheng et al., 2013). Because hypermethylation of tumor-suppressor gene promoters is a common characteristic of gastric cancer cells, inhibition of DNA methyltransferases has emerged as an effective strategy against gastric cancer (Egger et al., 2004).

Aberrant DNA methylation might be an important mechanism in EBV-related and MSI gastric carcinogenesis (Matsusaka et al., 2011). EBV-associated gastric cancer makes up almost $10 \%$ of all gastric cancers, which has special clinicopathological characteristics such as male predilection and preferential location in the cardia and middle part of the stomach (Cheng et al., 2015). EBV-positive tumors showed the highest degree of genome-wide hypermethylation and minimal demethylation, while MSI cancers accumulated a large number of promoter hypermethylation and demethylation out of promoter (Wang et al., 2014). Additionally, all EBV-positive tumors display CDKN2A $\left(\mathrm{p} 16^{\mathrm{INK} 4 \mathrm{~A}}\right)$ promoter hypermethylation, while MSI subtype exhibits the MLH1 hypermethylation. The extreme $\mathrm{CpG}$ island methylator phenotype in EBV-positive tumors is different from that in the MSI subtype, which mirrors differences between the two groups in their spectra of mutations and gene expression. EBV-positive tumors have a 
substantially higher frequency of promoter DNA hypermethylation and less gene mutations than MSI subtype (Cancer Genome Atlas Research, 2014; Wang et al., 2014).

Methylation of the $p 16$ gene promoter occurs continually in various human cancers, including colon, lung, breast, bladder and gastric cancers (Alves et al., 2011; Celebiler Cavusoglu et al., 2010; Jablonowski et al., 2011; Veganzones-de-Castro et al., 2012; Zhang et al., 2011a). P16, a member of the cyclin-dependent kinase inhibitor (CKI) family, blocks cells in the G1 phase and induces apoptosis through the activation of caspase-3 (Merlo et al., 1995). P16 shows high frequency and density of gene promoter methylation with a loss of expression ( $\mathrm{Na}$ and Woo, 2014). The demethylation agent 5-aza-dC markedly upregulates the expression of the pl6 gene and promotes cell apoptosis, suggesting that hypermethylation of the $p 16$ promoter might be involved in EBV-associated gastric carcinogenesis and demethylation therapy may be a novel therapeutic strategy for EBV-associated gastric cancer (He et al., 2015).

Several DNA-demethylating agents have been tested in clinical trials and have already been applied in clinical therapy, e.g., 5-azacytine and 5-aza-2'-deoxycytidine. Both of these agents are used to treat all subtypes of myelodysplastic syndrome and acute myelogenous leukemia (Kaminskas et al., 2005; Prakash et al., 2001; Yoo and Jones, 2006). DNA-demethylating agents used either alone or in combination with chemotherapeutic drugs and histone deacetylase inhibitors have been shown to be effective in the treatment of cancers. For instance, 5-aza-2'-eoxycyti-ne is used to treat ovarian cancer in combination with carboplatin (Appleton et al., 2007; Pohlmann et al., 2002). Promoter hypermethylation of tumor-suppressor genes, e.g., $P 16, C D H 1$, and $M L H 1$, occurs at a high frequency in gastric cancer cells. Several studies have shown that DNA demethylation is an effective strategy for the treatment of hypermethylation-associated gastric cancer (He et al., 2015; $\mathrm{Na}$ and Woo, 2014). There is no doubt that DNA methyltransferase inhibition is a potential remedy for gastric cancer.

\section{CONCLUSIONS}

A comprehensive understanding of the mechanisms underlying gastric cancer tumorigenesis is indispensable for therapeutic development. Although gastric cancer lags behind many other tumor types with respect to genetic sequencing and specific targeted therapies, recently published data employing second-generation sequencing have broadened our horizons regarding the genomic landscape of gastric cancer. A new molecular classification has been described and found to be correlated with the distinct salient genomic features among gastric cancer subtypes. The identification of these subtypes will offer a roadmap for patient stratification and trials of targeted therapies. Another notable achievement from the sequencing studies is the discovery of gain-of-function mutations in RhoA that are associated with gastric cancer tumorigenesis. Further investigation of RhoA-related therapies in gastric cancer may be beneficial for the improvement of patient survival.

Despite the continual emergence of genomic alterations in gastric cancer, few of these can be qualified as potential therapeutic targets, largely because loss-of-function mutations were thought to be intractable and hard to be targeted. The synthetic lethality theory provides new insights into the tightly correlated functions of distinct genes. Many synthetic lethal genes have been identified in tumor cells in which the tumor-suppressor genes were somehow silenced. These tumor-addicted genes may be validated as potential targets if selective toxicity in terms of genetic alterations is expected. However, many studies are needed to evaluate both the feasibility and the safety of these potential targets in gastric cancer treatment.

As the first valid functional target, HER2 overexpression is found in approximately $17 \%$ of gastric cancer patients. The anti-HER2 antibody trastuzumab has been demonstrated to be beneficial for the improvement of overall survival. Despite the success of trastuzumab in gastric cancer treatment, acquired resistance is inevitable. A better understanding of the molecular mechanisms underlying resistance is necessary to overcome this clinical problem. Moreover, the importance of combinatory strategies in the battle against resistance should never be underestimated if a sustainable response is desired.

Compliance and ethics The author(s) declare that they have no conflict of interest.

Acknowledgements This work was supported by the Science and Technology Commission of Shanghai Municipality (16ZR1410400, 14DZ2270100), and the State Scholarship Council (201506145040).

Abe, H., Maeda, D., Hino, R., Otake, Y., Isogai, M., Ushiku, A.S., Matsusaka, K., Kunita, A., Ushiku, T., Uozaki, H., Tateishi, Y., Hishima, T., Iwasaki, Y., Ishikawa, S., and Fukayama, M. (2012). ARID1A expression loss in gastric cancer: pathway-dependent roles with and without Epstein-Barr virus infection and microsatellite instability. Virchows Arch 461, 367-377.

Alves, M.K., Ferrasi, A.C., Lima, V.P., Ferreira, M.V., de Moura Campos Pardini, M.I., and Rabenhorst, S.H. (2011). Inactivation of COX-2, $H M L H 1$ and $C D K N 2 A$ gene by promoter methylation in gastric cancer: relationship with histological subtype, tumor location and Helicobacter pylori genotype. Pathobiology 78, 266-276.

An, S.M., Ding, Q.P., and Li, L.S. (2013). Stem cell signaling as a target for novel drug discovery: recent progress in the WNT and Hedgehog pathways. Acta Pharmacol Sin 34, 777-783.

Anastas, J.N., and Moon, R.T. (2013). WNT signalling pathways as therapeutic targets in cancer. Nat Rev Cancer 13, 11-26.

An, S.M., Ding, Q., Zhang, J., Xie, J.Y., and Li, L.S. (2014). Targeting stem cell signaling pathways for drug discovery: advances in the Notch 
and Wnt pathways. Sci China Life Sci 57, 575-580.

Appleton, K., Mackay, H.J., Judson, I., Plumb, J.A., McCormick, C., Strathdee, G., Lee, C., Barrett, S., Reade, S., Jadayel, D., Tang, A., Bellenger, K., Mackay, L., Setanoians, A., Schatzlein, A., Twelves, C., Kaye, S.B., and Brown, R. (2007). Phase I and pharmacodynamic trial of the DNA methyltransferase inhibitor decitabine and carboplatin in solid tumors. J Clin Oncol 25, 4603-4609.

Atencio, I.A., Grace, M., Bordens, R., Fritz, M., Horowitz, J.A., Hutchins, B., Indelicato, S., Jacobs, S., Kolz, K., Maneval, D., Musco, M.L., Shinoda, J., Venook, A., Wen, S., and Warren, R. (2006). Biological activities of a recombinant adenovirus p53 (SCH 58500) administered by hepatic arterial infusion in a Phase 1 colorectal cancer trial. Cancer Gene Ther 13, 169-181.

Attoub, S., Rivat, C., Rodrigues, S., Van Bocxlaer, S., Bedin, M., Bruyneel, E., Louvet, C., Kornprobst, M., Andre, T., Mareel, M., Mester, J., and Gespach, C. (2002). The c-kit tyrosine kinase inhibitor STI571 for colorectal cancer therapy. Cancer Res 62, 4879-4883.

Baron, J.A., Cole, B.F., Sandler, R.S., Haile, R.W., Ahnen, D., Bresalier, R., McKeown-Eyssen, G., Summers, R.W., Rothstein, R., Burke, C.A., Snover, D.C., Church, T.R., Allen, J.I., Beach, M., Beck, G.J., Bond, J.H., Byers, T., Greenberg, E.R., Mandel, J.S., Marcon, N., Mott, L.A., Pearson, L., Saibil, F., and van Stolk, R.U. (2003). A randomized trial of aspirin to prevent colorectal adenomas. N Engl J Med 348, 891-899.

Bellizzi, A., Mangia, A., Chiriatti, A., Petroni, S., Quaranta, M., Schittulli, F., Malfettone, A., Cardone, R.A., Paradiso, A., and Reshkin, S.J. (2008). RhoA protein expression in primary breast cancers and matched lymphocytes is associated with progression of the disease. Int $\mathbf{J} \mathrm{Mol}$ Med 22, 25-31.

Belyi, V.A., Ak, P., Markert, E., Wang, H., Hu, W., Puzio-Kuter, A., and Levine, A.J. (2010). The origins and evolution of the p53 family of genes. Cold Spring Harb Perspect Biol 2, a001198.

Bitler, B.G., Aird, K.M., Garipov, A., Li, H., Amatangelo, M., Kossenkov, A.V., Schultz, D.C., Liu, Q., Shih Ie, M., Conejo-Garcia, J.R., Speicher, D.W., and Zhang, R. (2015). Synthetic lethality by targeting EZH2 methyltransferase activity in ARID1A-mutated cancers. Nat Med 21, 231-238.

Bosse, T., ter Haar, N.T., Seeber, L.M., v Diest, P.J., Hes, F.J., Vasen, H.F., Nout, R.A., Creutzberg, C.L., Morreau, H., and Smit, V.T. (2013). Loss of ARID1A expression and its relationship with PI3K-Akt pathway alterations, TP53 and microsatellite instability in endometrial cancer. Mod Pathol 26, 1525-1535.

Bryant, H.E., Schultz, N., Thomas, H.D., Parker, K.M., Flower, D., Lopez, E., Kyle, S., Meuth, M., Curtin, N.J., and Helleday, T. (2005). Specific killing of BRCA2-deficient tumours with inhibitors of poly(ADPribose) polymerase. Nature 434, 913-917.

Buller, R.E., Runnebaum, I.B., Karlan, B.Y., Horowitz, J.A., Shahin, M., Buekers, T., Petrauskas, S., Kreienberg, R., Slamon, D., and Pegram, M. (2002). A phase I/II trial of $\mathrm{rAd} / p 53$ (SCH 58500) gene replacement in recurrent ovarian cancer. Cancer Gene Ther 9, 553-566.

Bykov, V.J., Issaeva, N., Shilov, A., Hultcrantz, M., Pugacheva, E., Chumakov, P., Bergman, J., Wiman, K.G., and Selivanova, G. (2002). Restoration of the tumor suppressor function to mutant p53 by a low-molecular-weight compound. Nat Med 8, 282-288.

Cancer Genome Atlas Research, N. (2014). Comprehensive molecular characterization of gastric adenocarcinoma. Nature 513, 202-209.

Cao, R., and Zhang, Y. (2004). The functions of E(Z)/EZH2-mediated methylation of lysine 27 in histone H3. Curr Opin Genet Dev 14, 155-164.

Caputo, A., Caci, E., Ferrera, L., Pedemonte, N., Barsanti, C., Sondo, E., Pfeffer, U., Ravazzolo, R., Zegarra-Moran, O., and Galietta, L.J. (2008). TMEM16A, a membrane protein associated with calcium-dependent chloride channel activity. Science 322, 590-594.

Carrera, S., Buque, A., Azkona, E., Aresti, U., Calvo, B., Sancho, A., Arruti, M., Nuno, M., Rubio, I., de Lobera, A.R., Lopez, C., and Vivanco, G.L. (2014). Epidermal growth factor receptor tyrosine-kinase inhibitor treatment resistance in non-small cell lung cancer: biological basis and therapeutic strategies. Clin Transl Oncol 16, 339-350.

Celebiler Cavusoglu, A., Sevinc, A.I., Saydam, S., Canda, T., Baskan, Z., Kilic, Y., and Sakizli, M. (2010). Promoter methylation and expression changes of $\mathrm{CDH} 1$ and $P 16$ genes in invasive breast cancer and adjacent normal breast tissue. Neoplasma 57, 465-472.

Cesar, A.C., Borim, A.A., Caetano, A., Cury, P.M., and Silva, A.E. (2004). Aneuploidies, deletion, and overexpression of TP53 gene in intestinal metaplasia of patients without gastric cancer. Cancer Genet Cytogenet 153, 127-132.

Chang, A.L., Solomon, J.A., Hainsworth, J.D., Goldberg, L., McKenna, E., Day, B.M., Chen, D.M., and Weiss, G.J. (2014). Expanded access study of patients with advanced basal cell carcinoma treated with the Hedgehog pathway inhibitor, vismodegib. J Am Acad Dermatol 70, 60-69.

Chen, G.X., Zheng, L.H., Liu, S.Y., and He, X.H. (2011). rAd-p53 enhances the sensitivity of human gastric cancer cells to chemotherapy. World J Gastroenterol 17, 4289-4297.

Chen, T., Yang, K., Yu, J., Meng, W., Yuan, D., Bi, F., Liu, F., Liu, J., Dai, B., Chen, X., Wang, F., Zeng, F., Xu, H., Hu, J., and Mo, X. (2012). Identification and expansion of cancer stem cells in tumor tissues and peripheral blood derived from gastric adenocarcinoma patients. Cell Res 22, 248-258.

Chen, W., Zhang, X., Chu, C., Cheung, W.L., Ng, L., Lam, S., Chow, A., Lau, T., Chen, M., Li, Y., Nie, Y., Wong, B.C., and Pang, R. (2013). Identification of $\mathrm{CD}_{4} 4^{+}$cancer stem cells in human gastric cancer. Hepatogastroenterology 60, 949-954.

Cheng, A., Li, M., Kang, W., Cheng, V., Chou, J., Lau, S.S., Go, M.Y., Lee, C.C., Ling, T., Ng, E.K., Yu, J., Huang, T., To, K.F., Chan, M., Sung, J., and Chan, F. (2013). Helicobacter pylori causes epigenetic dysregulation of FOXD3 to promote gastric carcinogenesis. Gastroenterology 144, 122-133.e9.

Cheng, N., Hui, D.Y., Liu, Y., Zhang, N., Jiang, Y., Han, J., Li, H., Ding, Y., Du, H., Chen, J., and Shao, C. (2015). Is gastric lymphoepithelioma-like carcinoma a special subtype of EBV-associated gastric carcinoma? New insight based on clinicopathological features and EBV genome polymorphisms. Gastric Cancer 18, 246-255.

Cohen, D.J., Christos, P.J., Kindler, H.L., Catenacci, D.V.T., Bekaii-Saab, T.B., Tahiri, S., Janjigian, Y.Y., Gibson, M.K., Chan, E., Rajdev, L., Urba, S., Wade, J.L., Kozuch, P., Love, E., Vandris, K., Takebe, N., Hochster, H.S., Sparano, J.A., and Consortium, N.Y.C. (2013). Vismodegib (V), a hedgehog (HH) pathway inhibitor, combined with FOLFOX for first-line therapy of patients (pts) with advanced gastric and gastroesophageal junction (GEJ) carcinoma: A New York Cancer Consortium led phase II randomized study. J Clin Oncol 31, 4011.

Cools, J. (2014). RHOA mutations in peripheral T cell lymphoma. Nat Genet 46, 320-321.

Egger, G., Liang, G., Aparicio, A., and Jones, P.A. (2004). Epigenetics in human disease and prospects for epigenetic therapy. Nature 429, 457-463.

Farmer, H., McCabe, N., Lord, C.J., Tutt, A.N., Johnson, D.A., Richardson, T.B., Santarosa, M., Dillon, K.J., Hickson, I., Knights, C., Martin, N.M., Jackson, S.P., Smith, G.C., and Ashworth, A. (2005). Targeting the DNA repair defect in BRCA mutant cells as a therapeutic strategy. Nature 434, 917-921.

Fritz, G., Just, I., and Kaina, B. (1999). Rho GTPases are over-expressed in human tumors. Int J Cancer 81, 682-687.

Fuereder, T., Wanek, T., Pflegerl, P., Jaeger-Lansky, A., Hoeflmayer, D., Strommer, S., Kuntner, C., Wrba, F., Werzowa, J., Hejna, M., Muller, M., Langer, O., and Wacheck, V. (2011). Gastric cancer growth control by BEZ235 in vivo does not correlate with PI3K/mTOR target inhibition but with [18F]FLT uptake. Clin Cancer Res 17, 5322-5332.

Fukui, K., Tamura, S., Wada, A., Kamada, Y., Sawai, Y., Imanaka, K., Kudara, T., Shimomura, I., and Hayashi, N. (2006). Expression and prognostic role of RhoA GTPases in hepatocellular carcinoma. J Cancer Res Clin Oncol 132, 627-633. 
Gamboa-Dominguez, A., Seidl, S., Reyes-Gutierrez, E., Hermannstadter, C., Quintanilla-Martinez, L., Busch, R., Hofler, H., Fend, F., and Luber, B. (2007). Prognostic significance of p21WAF1/CIP1, p27Kip1, p53 and E-cadherin expression in gastric cancer. J Clin Pathol 60, 756-761.

Gobbo Cesar, A.C., de Freitas Calmon, M., Cury, P.M., Caetano, A., Borim, A.A., and Silva, A.E. (2006). Genetic alterations in benign lesions: chronic gastritis and gastric ulcer. World J Gastroenterol 12, 625-629.

Gong, S.J., Jin, C.J., Rha, S.Y., and Chung, H.C. (2004). Growth inhibitory effects of trastuzumab and chemotherapeutic drugs in gastric cancer cell lines. Cancer Lett 214, 215-224.

Gravalos, C., Gomez-Martin, C., Rivera, F., Ales, I., Queralt, B., Marquez, A., Jimenez, U., Alonso, V., Garcia-Carbonero, R., Sastre, J., Colomer, R., Cortes-Funes, H., and Jimeno, A. (2011). Phase II study of trastuzumab and cisplatin as first-line therapy in patients with HER2-positive advanced gastric or gastroesophageal junction cancer. Clin Transl Oncol 13, 179-184.

Gravalos, C., and Jimeno, A. (2008). HER2 in gastric cancer: a new prognostic factor and a novel therapeutic target. Ann Oncol 19, 1523-1529.

Grosch, S., Tegeder, I., Niederberger, E., Brautigam, L., and Geisslinger, G. (2001). COX-2 independent induction of cell cycle arrest and apoptosis in colon cancer cells by the selective COX-2 inhibitor celecoxib. FASEB J 15, 2742-2744.

Group, G., Paoletti, X., Oba, K., Burzykowski, T., Michiels, S., Ohashi, Y., Pignon, J.P., Rougier, P., Sakamoto, J., Sargent, D., Sasako, M., Van Cutsem, E., and Buyse, M. (2010). Benefit of adjuvant chemotherapy for resectable gastric cancer: a meta-analysis. JAMA 303, 1729-1737.

Guan, B., Wang, T.L., and Shih Ie, M. (2011). ARID1A, a factor that promotes formation of SWI/SNF-mediated chromatin remodeling, is a tumor suppressor in gynecologic cancers. Cancer Res 71, 6718-6727.

Gur, S., Kadowitz, P.J., and Hellstrom, W.J. (2011). RhoA/Rho-kinase as a therapeutic target for the male urogenital tract. J Sex Med 8, 675-687.

He, D., Zhang, Y., Zhang, N., Zhou, L., Chen, J., Jiang, Y., and Shao, C. (2015). Aberrant gene promoter methylation of p16, FHIT, CRBP1, $W W O X$, and $D L C$-1 in Epstein-Barr virus-associated gastric carcinomas. Med Oncol 32, 92.

Iden, S., and Collard, J.G. (2008). Crosstalk between small GTPases and polarity proteins in cell polarization. Nat Rev Mol Cell Biol 9, 846-859.

Ikushima, H., and Miyazono, K. (2010). TGFbeta signalling: a complex web in cancer progression. Nat Rev Cancer 10, 415-424.

Inada, R., Sekine, S., Taniguchi, H., Tsuda, H., Katai, H., Fujiwara, T., and Kushima, R. (2015). ARID1A expression in gastric adenocarcinoma: clinicopathological significance and correlation with DNA mismatch repair status. World J Gastroenterol 21, 2159-2168.

Iwamatsu, H., Nishikura, K., Watanabe, H., Ajioka, Y., Hashidate, H., Kashimura, H., and Asakura, H. (2001). Heterogeneity of p53 mutational status in the superficial spreading type of early gastric carcinoma. Gastric Cancer 4, 20-26.

Jablonowski, Z., Reszka, E., Gromadzinska, J., Wasowicz, W., and Sosnowski, M. (2011). Hypermethylation of $p 16$ and DAPK promoter gene regions in patients with non-invasive urinary bladder cancer. Arch Med Sci 7, 512-516.

Jekimovs, C., Bolderson, E., Suraweera, A., Adams, M., O’Byrne, K.J., and Richard, D.J. (2014). Chemotherapeutic compounds targeting the DNA double-strand break repair pathways: the good, the bad, and the promising. Front Oncol 4, 86

Jemal, A., Bray, F., Center, M.M., Ferlay, J., Ward, E., and Forman, D. (2011). Global cancer statistics. CA Cancer J Clin 61, 69-90.

Justilien, V., and Fields, A.P. (2015). Molecular pathways: novel approaches for improved therapeutic targeting of Hedgehog signaling in cancer stem cells. Clin Cancer Res 21, 505-513.

Kahn, M. (2014). Can we safely target the WNT pathway? Nat Rev Drug Discov 13, 513-532.

Kakiuchi, M., Nishizawa, T., Ueda, H., Gotoh, K., Tanaka, A., Hayashi, A., Yamamoto, S., Tatsuno, K., Katoh, H., Watanabe, Y., Ichimura, T.,
Ushiku, T., Funahashi, S., Tateishi, K., Wada, I., Shimizu, N., Nomura, S., Koike, K., Seto, Y., Fukayama, M., Aburatani, H., and Ishikawa, S. (2014). Recurrent gain-of-function mutations of RHOA in diffuse-type gastric carcinoma. Nat Genet 46, 583-587.

Kaminskas, E., Farrell, A.T., Wang, Y.C., Sridhara, R., and Pazdur, R. (2005). FDA drug approval summary: azacitidine (5-azacytidine, Vidaza) for injectable suspension. Oncologist 10, 176-182.

Kang, G.H. (2012). CpG island hypermethylation in gastric carcinoma and its premalignant lesions. Korean J Pathol 46, 1-9.

Katuri, V., Tang, Y., Li, C., Jogunoori, W., Deng, C.X., Rashid, A., Sidawy, A.N., Evans, S., Reddy, E.P., Mishra, B., and Mishra, L. (2006). Critical interactions between TGF-beta signaling/ELF, and E-cadherin/beta-catenin mediated tumor suppression. Oncogene 25, 1871-1886.

Kim, M.S., Je, E.M., Yoo, N.J., and Lee, S.H. (2012). Loss of ARID1A expression is uncommon in gastric, colorectal, and prostate cancers. APMIS 120, 1020-1022.

Klampfer, L. (2014). Vitamin D and colon cancer. World J Gastrointest Oncol 6, 430-437.

Kobayashi, M., Kawashima, A., Mai, M., and Ooi, A. (1996). Analysis of chromosome 17p13 (p53 locus) alterations in gastric carcinoma cells by dual-color fluorescence in situ hybridization. Am J Pathol 149, 1575-1584.

Koo, B.K., Spit, M., Jordens, I., Low, T.Y., Stange, D.E., van de Wetering, M., van Es, J.H., Mohammed, S., Heck, A.J., Maurice, M.M., and Clevers, H. (2012). Tumour suppressor RNF43 is a stem-cell E3 ligase that induces endocytosis of Wnt receptors. Nature 488, 665-669.

Korkaya, H., Kim, G.I., Davis, A., Malik, F., Henry, N.L., Ithimakin, S., Quraishi, A.A., Tawakkol, N., D’Angelo, R., Paulson, A.K., Chung, S., Luther, T., Paholak, H.J., Liu, S., Hassan, K.A., Zen, Q., Clouthier, S.G., and Wicha, M.S. (2012). Activation of an IL6 inflammatory loop mediates trastuzumab resistance in HER2+ breast cancer by expanding the cancer stem cell population. Mol Cell 47, 570-584.

Lagasse, E. (2008). Cancer stem cells with genetic instability: the best vehicle with the best engine for cancer. Gene Ther 15, 136-142.

Larriba, M.J., Ordonez-Moran, P., Chicote, I., Martin-Fernandez, G., Puig, I., Munoz, A., and Palmer, H.G. (2011). Vitamin D receptor deficiency enhances Wnt/beta-catenin signaling and tumor burden in colon cancer. PLoS One 6, e23524.

Lauren, P. (1965). The two histological main types of gastric carcinoma: diffuse and so-called intestinal-type carcinoma. An attempt at a histo-clinical classification. Acta Pathol Microbiol Scand 64, 31-49.

Lee, H.E., Han, N., Kim, M.A., Lee, H.S., Yang, H.K., Lee, B.L., and Kim, W.H. (2014). DNA damage response-related proteins in gastric cancer: ATM, Chk2 and p53 expression and their prognostic value. Pathobiology $81,25-35$.

Lehmann, S., Bykov, V.J., Ali, D., Andren, O., Cherif, H., Tidefelt, U., Uggla, B., Yachnin, J., Juliusson, G., Moshfegh, A., Paul, C., Wiman, K.G., and Andersson, P.O. (2012). Targeting p53 in vivo: a first-in-human study with p53-targeting compound APR-246 in refractory hematologic malignancies and prostate cancer. J Clin Oncol 30, 3633-3639.

Leite, M., Corso, G., Sousa, S., Milanezi, F., Afonso, L.P., Henrique, R., Soares, J.M., Castedo, S., Carneiro, F., Roviello, F., Oliveira, C., and Seruca, R. (2011). MSI phenotype and MMR alterations in familial and sporadic gastric cancer. Int J Cancer 128, 1606-1613.

Levy, L., and Hill, C.S. (2005). Smad4 dependency defines two classes of transforming growth factor \{beta\} (TGF-\{beta\}) target genes and distinguishes TGF-\{beta\}-induced epithelial-mesenchymal transition from its antiproliferative and migratory responses. Mol Cell Biol 25, 8108-8125.

Liang, H., Cheung, L.W., Li, J., Ju, Z., Yu, S., Stemke-Hale, K., Dogruluk, T., Lu, Y., Liu, X., Gu, C., Guo, W., Scherer, S.E., Carter, H., Westin, S.N., Dyer, M.D., Verhaak, R.G., Zhang, F., Karchin, R., Liu, C., Lu, K., Broaddus, R.R., Scott, K.L., Hennessy, B.T., and Mills, G.B. 
(2012). Whole-exome sequencing combined with functional genomics reveals novel candidate driver cancer genes in endometrial cancer. Genome Res 22, 2120-2129.

Liu, F., Cao, Q., Lu, J., Luo, B., Lu, X., Luo, R., and Wang, X. (2015). TMEM16A overexpression contributes to tumor invasion and poor prognosis of human gastric cancer through TGF-beta signaling. Oncotarget 6, 11585-11599.

Liu, L., Lai, C.Q., Nie, L., Ordovas, J., Band, M., Moser, L., and Meydani, M. (2008). The modulation of endothelial cell gene expression by green tea polyphenol-EGCG. Mol Nutr Food Res 52, 1182-1192.

Liu, X., Wang, S., Xia, X., Chen, Y., Zhou, Y., Wu, X., Zhang, J., He, S., Tan, Y., Qiang, F., Roe, O.D., Li, G., and Zhou, J. (2012). Synergistic role between p53 and JWA: prognostic and predictive biomarkers in gastric cancer. PLoS One 7, e52348.

Lu, H., Wu, Y., Luo, W., Han, Y., Cai, Y., Xu, X., Liang, J., Liu, S., and Wang, M. (2009a). Correlation between aneuploidy of chromosome 17, over-expression of TP53 and TOPIIalpha, and the clinicopathological features and diagnosis of gastric adenocarcinoma. Zhonghua Zhong Liu Za Zhi 31, 754-758.

Lu, Q., Longo, F.M., Zhou, H., Massa, S.M., and Chen, Y.H. (2009b). Signaling through Rho GTPase pathway as viable drug target. Curr Med Chem 16, 1355-1365.

Mali, R.S., Ramdas, B., Ma, P., Shi, J., Munugalavadla, V., Sims, E., Wei, L., Vemula, S., Nabinger, S.C., Goodwin, C.B., Chan, R.J., Traina, F., Visconte, V., Tiu, R.V., Lewis, T.A., Stern, A.M., Wen, Q., Crispino, J.D., Boswell, H.S., and Kapur, R. (2011). Rho kinase regulates the survival and transformation of cells bearing oncogenic forms of KIT, FLT3, and BCR-ABL. Cancer Cell 20, 357-369.

Malissein, E., Meunier, E., Lajoie-Mazenc, I., Medale-Giamarchi, C., Dalenc, F., and Doisneau-Sixou, S.F. (2013). RhoA and RhoC differentially modulate estrogen receptor alpha recruitment, transcriptional activities, and expression in breast cancer cells (MCF-7). J Cancer Res Clin Oncol 139, 2079-2088.

Matsusaka, K., Kaneda, A., Nagae, G., Ushiku, T., Kikuchi, Y., Hino, R., Uozaki, H., Seto, Y., Takada, K., Aburatani, H., and Fukayama, M. (2011). Classification of Epstein-Barr virus-positive gastric cancers by definition of DNA methylation epigenotypes. Cancer Res 71, 7187-7197.

Merlo, A., Herman, J.G., Mao, L., Lee, D.J., Gabrielson, E., Burger, P.C., Baylin, S.B., and Sidransky, D. (1995). 5' CpG island methylation is associated with transcriptional silencing of the tumour suppressor p16/CDKN2/MTS1 in human cancers. Nat Med 1, 686-692.

Mishra, L., Shetty, K., Tang, Y., Stuart, A., and Byers, S.W. (2005). The role of TGF-beta and Wnt signaling in gastrointestinal stem cells and cancer. Oncogene 24, 5775-5789.

Molina, M.A., Codony-Servat, J., Albanell, J., Rojo, F., Arribas, J., and Baselga, J. (2001). Trastuzumab (herceptin), a humanized anti-Her2 receptor monoclonal antibody, inhibits basal and activated Her2 ectodomain cleavage in breast cancer cells. Cancer Res 61, 4744-4749.

Molli, P.R., Pradhan, M.B., Advani, S.H., and Naik, N.R. (2012). RhoA: a therapeutic target for chronic myeloid leukemia. Mol Cancer 11, 16.

Na, H.K., and Woo, J.H. (2014). Helicobacter pylori induces hypermethylation of $\mathrm{CpG}$ islands through upregulation of DNA methyltransferase: possible involvement of reactive oxygen/nitrogen species. J Cancer Prev 19, 259-264.

Nagy, P., Friedlander, E., Tanner, M., Kapanen, A.I., Carraway, K.L., Isola, J., and Jovin, T.M. (2005). Decreased accessibility and lack of activation of ErbB2 in JIMT-1, a herceptin-resistant, MUC4-expressing breast cancer cell line. Cancer Res 65, 473-482.

Nahta, R. (2012). Molecular mechanisms of trastuzumab-based treatment in HER2-overexpressing breast cancer. ISRN Oncol 2012, 428062.

Narumiya, S., Tanji, M., and Ishizaki, T. (2009). Rho signaling, ROCK and mDia1, in transformation, metastasis and invasion. Cancer Metastasis Rev 28, 65-76.

Nunes, K.P., Rigsby, C.S., and Webb, R.C. (2010). RhoA/Rho-kinase and vascular diseases: what is the link? Cell Mol Life Sci 67, 3823-3836.

Oh, S., Gwak, J., Park, S., and Yang, C. (2014). Green tea polyphenol EGCG suppresses Wnt/beta-catenin signaling by promoting GSK-3beta- and PP2A-independent beta-catenin phosphorylation/degradation. Biofactors 40, 586-595.

Oki, E., Zhao, Y., Yoshida, R., Egashira, A., Ohgaki, K., Morita, M., Kakeji, Y., and Maehara, Y. (2009). The difference in p53 mutations between cancers of the upper and lower gastrointestinal tract. Digestion 79 Suppl 1, 33-39.

Olson, M.F. (2008). Applications for ROCK kinase inhibition. Curr Opin Cell Biol 20, 242-248.

Palomero, T., Couronne, L., Khiabanian, H., Kim, M.Y., Ambesi-Impiombato, A., Perez-Garcia, A., Carpenter, Z., Abate, F., Allegretta, M., Haydu, J.E., Jiang, X., Lossos, I.S., Nicolas, C., Balbin, M., Bastard, C., Bhagat, G., Piris, M.A., Campo, E., Bernard, O.A., Rabadan, R., and Ferrando, A.A. (2014). Recurrent mutations in epigenetic regulators, RHOA and FYN kinase in peripheral T cell lymphomas. Nat Genet 46, 166-170.

Park, H.J., Kim, H.S., Kim, J.W., Park, S.Y., Kim, B.R., Ryu, H.Y., Lee, I.Y., Lee, Y.K., and Cho, M.Y. (2013). Is microsatellite instability (MSI) associated with multiplicity in early stage gastric neoplasias? Clin Res Hepatol Gastroenterol 37, 400-405.

Park, S.H., Kim, Y.S., Park, B.K., Hougaard, S., and Kim, S.J. (2001). Sequence-specific enhancer binding protein is responsible for the differential expression of ERT/ESX/ELF-3/ESE-1/jen gene in human gastric cancer cell lines: implication for the loss of TGF-beta type II receptor expression. Oncogene 20, 1235-1245.

Pohlmann, P., DiLeone, L.P., Cancella, A.I., Caldas, A.P., Dal Lago, L., Campos, O., Jr., Monego, E., Rivoire, W., and Schwartsmann, G. (2002). Phase II trial of cisplatin plus decitabine, a new DNA hypomethylating agent, in patients with advanced squamous cell carcinoma of the cervix. Am J Clin Oncol 25, 496-501.

Prakash, S., Foster, B.J., Meyer, M., Wozniak, A., Heilbrun, L.K., Flaherty, L., Zalupski, M., Radulovic, L., Valdivieso, M., and LoRusso, P.M. (2001). Chronic oral administration of CI-994: a phase 1 study. Invest New Drugs 19, 1-11.

Qu, Y., Dang, S., and Hou, P. (2013). Gene methylation in gastric cancer. Clin Chim Acta 424, 53-65.

Ryu, K.D., Kim, G.H., Park, S.O., Lee, K.J., Moon, J.Y., Jeon, H.K., Baek, D.H., Lee, B.E., and Song, G.A. (2014). Treatment outcome for gastric mucosa-associated lymphoid tissue lymphoma according to Helicobacter pylori infection status: a single-center experience. Gut Liver 8, $408-414$.

Sadok, A., McCarthy, A., Caldwell, J., Collins, I., Garrett, M.D., Yeo, M., Hooper, S., Sahai, E., Kuemper, S., Mardakheh, F.K., and Marshall, C.J. (2015). Rho kinase inhibitors block melanoma cell migration and inhibit metastasis. Cancer Res 75, 2272-2284.

Sahai, E., and Marshall, C.J. (2002). RHO-GTPases and cancer. Nat Rev Cancer 2, 133-142.

Sakata-Yanagimoto, M., Enami, T., Yoshida, K., Shiraishi, Y., Ishii, R., Miyake, Y., Muto, H., Tsuyama, N., Sato-Otsubo, A., Okuno, Y., Sakata, S., Kamada, Y., Nakamoto-Matsubara, R., Tran, N.B., Izutsu, K., Sato, Y., Ohta, Y., Furuta, J., Shimizu, S., Komeno, T., Sato, Y., Ito, T., Noguchi, M., Noguchi, E., Sanada, M., Chiba, K., Tanaka, H., Suzukawa, K., Nanmoku, T., Hasegawa, Y., Nureki, O., Miyano, S., Nakamura, N., Takeuchi, K., Ogawa, S., and Chiba, S. (2014). Somatic RHOA mutation in angioimmunoblastic T cell lymphoma. Nat Genet 46, 171-175.

Samartzis, E.P., Gutsche, K., Dedes, K.J., Fink, D., Stucki, M., and Imesch, P. (2014). Loss of ARID1A expression sensitizes cancer cells to PI3K- and AKT-inhibition. Oncotarget 5, 5295-5303.

Sandhiya, S., Melvin, G., Kumar, S.S., and Dkhar, S.A. (2013). The dawn of hedgehog inhibitors: Vismodegib. J Pharmacol Pharmacother 4, 4-7.

Sandler, R.S., Halabi, S., Baron, J.A., Budinger, S., Paskett, E., Keresztes, R., Petrelli, N., Pipas, J.M., Karp, D.D., Loprinzi, C.L., Steinbach, G., 
and Schilsky, R. (2003). A randomized trial of aspirin to prevent colorectal adenomas in patients with previous colorectal cancer. $\mathrm{N}$ Engl J Med 348, 883-890.

Senzer, N., and Nemunaitis, J. (2009). A review of contusugene ladenovec (Advexin) p53 therapy. Curr Opin Mol Ther 11, 54-61.

Shang, X., Marchioni, F., Evelyn, C.R., Sipes, N., Zhou, X., Seibel, W., Wortman, M., and Zheng, Y. (2013). Small-molecule inhibitors targeting G-protein-coupled Rho guanine nucleotide exchange factors. Proc Natl Acad Sci USA 110, 3155-3160.

Shang, X., Marchioni, F., Sipes, N., Evelyn, C.R., Jerabek-Willemsen, M., Duhr, S., Seibel, W., Wortman, M., and Zheng, Y. (2012). Rational design of small molecule inhibitors targeting RhoA subfamily Rho GTPases. Chem Biol 19, 699-710.

Siegel, R., Naishadham, D., and Jemal, A. (2013). Cancer statistics, 2013. CA Cancer J Clin 63, 11-30.

Smith, M.G., Hold, G.L., Tahara, E., and El-Omar, E.M. (2006). Cellular and molecular aspects of gastric cancer. World J Gastroenterol 12, 2979-2990.

So, J.Y., and Suh, N. (2015). Targeting cancer stem cells in solid tumors by vitamin D. J Steroid Biochem Mol Biol 148, 79-85.

Stojnev, S., Krstic, M., Ristic-Petrovic, A., Stefanovic, V., and Hattori, T. (2014). Gastric cancer stem cells: therapeutic targets. Gastric Cancer $17,13-25$.

Strong, M.J., Xu, G., Coco, J., Baribault, C., Vinay, D.S., Lacey, M.R., Strong, A.L., Lehman, T.A., Seddon, M.B., Lin, Z., Concha, M., Baddoo, M., Ferris, M., Swan, K.F., Sullivan, D.E., Burow, M.E., Taylor, C.M., and Flemington, E.K. (2013). Differences in gastric carcinoma microenvironment stratify according to EBV infection intensity: implications for possible immune adjuvant therapy. PLoS Pathog 9, e1003341.

Sumiyoshi, Y., Kakeji, Y., Egashira, A., Mizokami, K., Orita, H., and Maehara, Y. (2006). Overexpression of hypoxia-inducible factor 1alpha and p53 is a marker for an unfavorable prognosis in gastric cancer. Clin Cancer Res 12, 5112-5117.

Suzuki, K., and Matsubara, H. (2011). Recent advances in p53 research and cancer treatment. J Biomed Biotechnol 2011, 978312.

Tahara, E. (2004). Genetic pathways of two types of gastric cancer. IARC Sci Publ, 327-349.

Tang, Y., Katuri, V., Srinivasan, R., Fogt, F., Redman, R., Anand, G., Said, A., Fishbein, T., Zasloff, M., Reddy, E.P., Mishra, B., and Mishra, L. (2005). Transforming growth factor-beta suppresses nonmetastatic colon cancer through Smad4 and adaptor protein ELF at an early stage of tumorigenesis. Cancer Res 65, 4228-4237.

Ushiku, T., Ishikawa, S., Kakiuchi, M., Tanaka, A., Katoh, H., Aburatani, H., Lauwers, G.Y., and Fukayama, M. (2015). RHOA mutation in diffuse-type gastric cancer: a comparative clinicopathology analysis of 87 cases. Gastric Cancer 19, 403-411.

van Beusechem, V.W., van den Doel, P.B., Grill, J., Pinedo, H.M., and Gerritsen, W.R. (2002). Conditionally replicative adenovirus expressing p53 exhibits enhanced oncolytic potency. Cancer Res 62, 6165-6171.

Veganzones-de-Castro, S., Rafael-Fernandez, S., Vidaurreta-Lazaro, M., de-la-Orden, V., Mediero-Valeros, B., Fernandez, C., and Maestro-de las Casas, M.L. (2012). p16 gene methylation in colorectal cancer patients with long-term follow-up. Rev Esp Enferm Dig 104, 111-117.

Velho, S., Oliveira, C., Ferreira, A., Ferreira, A.C., Suriano, G., Schwartz, S., Jr., Duval, A., Carneiro, F., Machado, J.C., Hamelin, R., and Seruca, R. (2005). The prevalence of $P I K_{3} C A$ mutations in gastric and colon cancer. Eur J Cancer 41, 1649-1654.

Venkatanarayan, A., Raulji, P., Norton, W., Chakravarti, D., Coarfa, C., Su, X., Sandur, S.K., Ramirez, M.S., Lee, J., Kingsley, C.V., Sananikone, E.F., Rajapakshe, K., Naff, K., Parker-Thornburg, J., Bankson, J.A., Tsai, K.Y., Gunaratne, P.H., and Flores, E.R. (2015). IAPP-driven metabolic reprogramming induces regression of p53-deficient tumours in vivo. Nature 517, 626-630.
Wang, D., Chen, Y., Pan, K., Wang, W., Chen, S., Chen, J., Zhao, J., Lv, L., Pan, Q., Li, Y., Wang, Q., Huang, L., Ke, M., He, J., and Xia, J. (2012). Decreased expression of the ARID1A gene is associated with poor prognosis in primary gastric cancer. PLoS One 7, e40364.

Wang, K., Kan, J., Yuen, S.T., Shi, S.T., Chu, K.M., Law, S., Chan, T.L., Kan, Z., Chan, A.S., Tsui, W.Y., Lee, S.P., Ho, S.L., Chan, A.K., Cheng, G.H., Roberts, P.C., Rejto, P.A., Gibson, N.W., Pocalyko, D.J., Mao, M., Xu, J., and Leung, S.Y. (2011). Exome sequencing identifies frequent mutation of ARIDIA in molecular subtypes of gastric cancer. Nat Genet 43, 1219-1223.

Wang, K., Yuen, S.T., Xu, J., Lee, S.P., Yan, H.H., Shi, S.T., Siu, H.C., Deng, S., Chu, K.M., Law, S., Chan, K.H., Chan, A.S., Tsui, W.Y., Ho, S.L., Chan, A.K., Man, J.L., Foglizzo, V., Ng, M.K., Chan, A.S., Ching, Y.P., Cheng, G.H., Xie, T., Fernandez, J., Li, V.S., Clevers, H., Rejto, P.A., Mao, M., and Leung, S.Y. (2014). Whole-genome sequencing and comprehensive molecular profiling identify new driver mutations in gastric cancer. Nat Genet 46, 573-582.

Wang, X., Su, C., Cao, H., Li, K., Chen, J., Jiang, L., Zhang, Q., Wu, X., Jia, X., Liu, Y., Wang, W., Liu, X., Wu, M., and Qian, Q. (2008). A novel triple-regulated oncolytic adenovirus carrying $p 53$ gene exerts potent antitumor efficacy on common human solid cancers. Mol Cancer Ther 7, 1598-1603.

Wei, K., Jiang, L., Wei, Y., Wang, Y., Qian, X., Dai, Q., and Guan, Q. (2015). The prognostic significance of $p 53$ expression in gastric cancer: a meta-analysis. J Cancer Res Clin Oncol 141, 735-748.

Wilkes, G.M. (2012). Vismodegib, a hedgehog pathway inhibitor for adults with locally advanced or metastatic basal cell carcinoma. Oncology (Williston Park) 26, 31-33.

Wolf, J.K., Bodurka, D.C., Gano, J.B., Deavers, M., Ramondetta, L., Ramirez, P.T., Levenback, C., and Gershenson, D.M. (2004). A phase I study of Adp53 (INGN 201; ADVEXIN) for patients with platinumand paclitaxel-resistant epithelial ovarian cancer. Gynecol Oncol 94, $442-448$.

Xia, M., and Land, H. (2007). Tumor suppressor p53 restricts Ras stimulation of RhoA and cancer cell motility. Nat Struct Mol Biol 14, 215-223.

Xie, S., Zhang, Y., Li, Q., Wang, J., Li, J., Zhao, J., and Wang, C. (2012). COX-2-independent induction of apoptosis by celecoxib and polyamine naphthalimide conjugate mediated by polyamine depression in colorectal cancer cell lines. Int J Colorectal Dis 27, 861-868.

Yamamoto, S., Tsuda, H., Takano, M., Tamai, S., and Matsubara, O. (2012). PIK3CA mutations and loss of ARID1A protein expression are early events in the development of cystic ovarian clear cell adenocarcinoma. Virchows Arch 460, 77-87.

Yamasaki, Y., Tazawa, H., Hashimoto, Y., Kojima, T., Kuroda, S., Yano, S., Yoshida, R., Uno, F., Mizuguchi, H., Ohtsuru, A., Urata, Y., Kagawa, S., and Fujiwara, T. (2012). A novel apoptotic mechanism of genetically engineered adenovirus-mediated tumour-specific p53 overexpression through E1A-dependent p21 and MDM2 suppression. Eur J Cancer 48, 2282-2291.

Yang, W., Raufi, A., and Klempner, S.J. (2014). Targeted therapy for gastric cancer: molecular pathways and ongoing investigations. Biochim Biophys Acta 1846, 232-237.

Yano, T., Doi, T., Ohtsu, A., Boku, N., Hashizume, K., Nakanishi, M., and Ochiai, A. (2006). Comparison of HER2 gene amplification assessed by fluorescence in situ hybridization and HER2 protein expression assessed by immunohistochemistry in gastric cancer. Oncol Rep 15, 65-71.

Yao, J., Qian, C., Shu, T., Zhang, X., Zhao, Z., and Liang, Y. (2013). Combination treatment of PD98059 and DAPT in gastric cancer through induction of apoptosis and downregulation of WNT/beta-catenin. Cancer Biol Ther 14, 833-839.

Yoo, C.B., and Jones, P.A. (2006). Epigenetic therapy of cancer: past, present and future. Nat Rev Drug Discov 5, 37-50.

Yoo, H.Y., Sung, M.K., Lee, S.H., Kim, S., Lee, H., Park, S., Kim, S.C., Lee, B., Rho, K., Lee, J.E., Cho, K.H., Kim, W., Ju, H., Kim, J., Kim, 
S.J., Kim, W.S., Lee, S., and Ko, Y.H. (2014). A recurrent inactivating mutation in RHOA GTPase in angioimmunoblastic $\mathrm{T}$ cell lymphoma. Nat Genet 46, 371-375.

Zang, Z.J., Cutcutache, I., Poon, S.L., Zhang, S.L., McPherson, J.R., Tao, J., Rajasegaran, V., Heng, H.L., Deng, N., Gan, A., Lim, K.H., Ong, C.K., Huang, D., Chin, S.Y., Tan, I.B., Ng, C.C., Yu, W., Wu, Y., Lee, M., Wu, J., Poh, D., Wan, W.K., Rha, S.Y., So, J., Salto-Tellez, M., Yeoh, K.G., Wong, W.K., Zhu, Y.J., Futreal, P.A., Pang, B., Ruan, Y., Hillmer, A.M., Bertrand, D., Nagarajan, N., Rozen, S., Teh, B.T., and Tan, P. (2012). Exome sequencing of gastric adenocarcinoma identifies recurrent somatic mutations in cell adhesion and chromatin remodeling genes. Nat Genet 44, 570-574.

Zhang, A., Wang, Q., Han, Z., Hu, W., Xi, L., Gao, Q., Wang, S., Zhou, J., Xu, G., Meng, L., Chen, G., and Ma, D. (2013). Reduced expression of
Snail decreases breast cancer cell motility by downregulating the expression and inhibiting the activity of RhoA GTPase. Oncol Lett 6, 339-346.

Zhang, B., Zhu, W., Yang, P., Liu, T., Jiang, M., He, Z.N., Zhang, S., Chen, W., and Chen, W. (2011a). Cigarette smoking and p16INK4alpha gene promoter hypermethylation in non-small cell lung carcinoma patients: a meta-analysis. PLoS One 6, e28882.

Zhang, C., Li, C., He, F., Cai, Y., and Yang, H. (2011b). Identification of $\mathrm{CD} 44^{+} \mathrm{CD} 24^{+}$gastric cancer stem cells. J Cancer Res Clin Oncol 137, 1679-1686.

Zhao, C. (2014). Paracrine signaling in stem cell renewal and in neoplastic tumor growth. Sci China Life Sci 57, 571-574.

Zhou, J., Hayakawa, Y., Wang, T.C., and Bass, A.J. (2014). RhoA mutations identified in diffuse gastric cancer. Cancer Cell 26, 9-11. 